\title{
PENELITIAN
}

\section{PELUANG KETAHANAN HIDUP 5 TAHUN PASIEN KANKER SERVIKS DI RSUPN Dr CIPTO MANGUNKUSUMO \& RSK DHARMAIS, JAKARTA, 2002}

\author{
Dewi Gayatri *, Besral **, Elly Nurachmah ***
}

\begin{abstract}
Abstrak
Kematian akibat kanker di dunia semakin meningkat baik di negara maju maupun berkembang. Di Indonesia, data menunjukkan hal serupa. Registrasi kanker di Indonesia berdasarkan kependudukan belum ada serta penelitian yang berkaitan dengan ketahanan hidup kanker serviks sangat kurang. Hal ini membuat peneliti tertarik untuk mengukur ketahanan hidup 5 tahun pasien kanker serviks. Desain penelitian ini adalah kohort retrospektif pada 451 subyek penelitian dengan mengunakan data rekam medis pada diagnosis tahun 1993-1996 yang diikuti selama 5 tahun. Hasil penelitian ini menyimpulkan bahwa probabilitas ketahanan hidup 5 tahun pasien kanker serviks dengan stadium I sekitar 70\%, stadium II sekitar 37,4\%, stadium III sekitar 12,4\%, dan stadium IV pada tahun kedua sudah menjadi $0 \%$.
\end{abstract}

Kata kunci: ketahanan hidup, probabilitas, kanker serviks, analisis kesintasan

\begin{abstract}
Abstrack
The caused of death by cancer was increase both in the developed countries and developing countries. In Indonesia, the data shows the same pattern. In Indonesia, population based cancer registry was not yet developed furthermore lack of research related to survival rate of cervical cancer. This situation made author interested to know the probability of five-years survival of cervical cancer patient. The design of this study is retrospective cohort among 451 subjects, the data was collected form the medical record of cervical cancer patient those who was diagnosed during 1993-1996 and then followed up to 5 years. The result of this study is conclude that the probability of 5-years survival of cervical cancer patient with the stage-I is $70 \%$, stage-II is about $37,4 \%$, stage-III is about 12,4\%, and stage-IV was to be $0 \%$ at the second year.
\end{abstract}

Key words: survival, probability, cervical cancer, survival analysis

Penelitian dibiayai oleh Gudosin

\section{LATAR BELAKANG}

Dewasa ini dirasakan bahwa masalah kanker semakin meningkat dibandingkan sepuluh atau dua puluh tahun yang lalu. Departemen Kesehatan melaporkan sekitar 3,5\% pasien yang dirawat di rumah sakit (RS) adalah neoplasma dan cenderung menjadi salah satu penyebab utama kematian pada usia produktif. Depkes (1996) melaporkan bahwa pada Survey Kesehatan Rumah tangga (SKRT) (1996) menunjukkan proporsi penyebab kematian karena kanker meningkat dari $1,3 \%$ pada tahun 1976 menjadi 5\% pada tahun 1995.

Badan Litbangkes membuat perkiraan insidens kanker di Indonesia sebesar 100 per 100.000 orang. Hasil laporan di 15 laboratorium patologi anatomi di seluruh Indonesia tahun 1990 diketahui bahwa kanker servik menempati urutan pertama dari tiga kanker yang tersering dijumpai kemudian diikuti kanker payudara dan kanker kelenjar limfe. Data gabungan dari beberapa RS menyebutkan bahwa kanker servik memiliki frekuensi tertinggi di antara penyakit lainnya (Aziz, 1996).

Stadium klinik merupakan indikator prognostik (penduga) terbaik adanya kanker serviks pada pasien. Pengobatan atau penatalaksanaan disesuaikan dengan stadium klinik pasien. Keberhasilan pengobatan kanker dinyatakan dengan angka perbandingan pasien yang masih tetap hidup dengan jumlah keseluruhan pasien setelah pengobatan diberikan dalam jangka waktu tertentu, biasanya 5 tahun untuk semua sta- 
dium atau 10 tahun untuk stadium I (De Vita dkk, 1995). Angka perbandingan inilah yang selanjutnya akan disebut sebagai probabilitas ketahanan hidup di mana peluang ini berkisar dari 0 hingga 1 atau dapat pula dinyatakan dalam persen.

Di Indonesia, penelitian kanker serviks lebih tertuju pada faktor-faktor predisposisi sedangkan yang berkaitan dengan ketahanan hidup pasien kanker serviks masih jarang dilakukan. Alasan inilah yang mendorong peneliti untuk mengetahui dan mengukur probabilitas ketahanan hidup 5 tahun pasien kanker serviks di RSUPN Dr Cipto Mangunkusumo (RSUPN CM) dan RSK Dharmais (RSKD), Jakarta.

\section{TUJUAN}

Penelitian bertujuan mengetahui probabilitas ketahanan hidup 5 tahun pada pasien kanker serviks dan risiko untuk meninggal berdasarkan masingmasing stadium klinik.

\section{METODOLOGI}

Penelitian ini merupakan studi analitik dengan desain kohort retrospektif. Adapun data yang dianalisis berdasarkan data rekam medis di 2 RS. Data rekam medis diambil pada 1993-1996 dan masing-masing data tersebut diikuti selama 5 tahun sejak pertama kali pasien didiagnosis.

Analisis data yang digunakan dalam penelitian ini adalah univariat dan bivariat..Karena variabel hasil yang ingin diukur dalam waktu maka penelitian ini menggunakan analisis kesintasan dengan metoda life table sedangkan untuk melihat kemaknaannya digunakan uji Wilcoxon. Untuk mengetahui risiko relatif untuk meninggal, maka digunakan regresi Cox.

\section{HASIL}

Hasil pengumpulan data rekam medis tahun 1993-1996 di RSUPN CM dan RSKD yang dilakukan selama kurang lebih 2 bulan, didapatkan data sebanyak 455 subyek dengan perincian data dari RSUPN CM sebanyak 142 subyek $(31,2 \%)$ sedangkan dari RSKD sebanyak 313 subyek $(68,8 \%)$. Dari data tersebut diketahui bahwa sebanyak 42 subyek $(9,2 \%)$ diketahui masih hidup, 198 subyek $(43,5 \%)$ diketahui sudah meninggal, sedangkan sisanya 215 subyek ( 47,3\%) tidak diketahui (hilang dari pengamatan) dengan 4 subyek diketahui hanya berobat jalan sehingga waktu perawatan hanya 1-2 hari. Subyek yang hilang dari pengamatan akan digabung dengan subyek hidup menjadi sensor sedangkan subyek meninggal menjadi kejadian/ event.

\section{Analisis Univariat Ketahanan Hidup}

\section{Waktu Ketahanan Hidup Pasien Kanker Serviks}

Gambaran waktu ketahanan hidup pasien tidak terdistribusi secara normal, hal ini diketahui dari tes Kolmogorov Smirnov dengan $\mathrm{p}=0.000$ selain itu dari gambaran histogram juga menunjukkan hal yang sama.

Analisis univariat untuk mengukur variabel ketahanan hidup pasien kanker serviks pada penelitian ini menggunakan metoda Life Table karena ketahanan hidup dalam penelitian ini dibagi menjadi interval waktu. Untuk mengukur waktu ketahanan hidup 5 tahun, peneliti membaginya menjadi 5 titik pengamatan dengan jarak masing-masing interval 1 tahun.

Grafik 1 memperlihatkan probabilitas ketahanan hidup menurut waktu ketahanan hidup. Dalam gambar tersebut waktu ketahanan hidup ditunjukkan dalam satuan tahun, nilai 0 hingga 5 tahun (lamanya pengamatan), dengan interval setiap 1 tahun. Nilai probabilitas berkisar 0 sampai 1 atau dapat pula dibaca dalam persen yang berarti nilainya 0 hingga $100 \%$. Didapatkan probabilitas ketahanan hidup pasien kanker serviks pada tahun pertama sebesar $48 \%$ sedangkan pada probabilitas kumulatif pada tahun kelima sebesar $27 \%$ dengan median ketahanan hidup sebesar 1,91 tahun.

Grafik 1

Distribusi waktu ketahanan hidup 5 tahun pasien kanker serviks, RSUPN CM\&RSKD, 2002

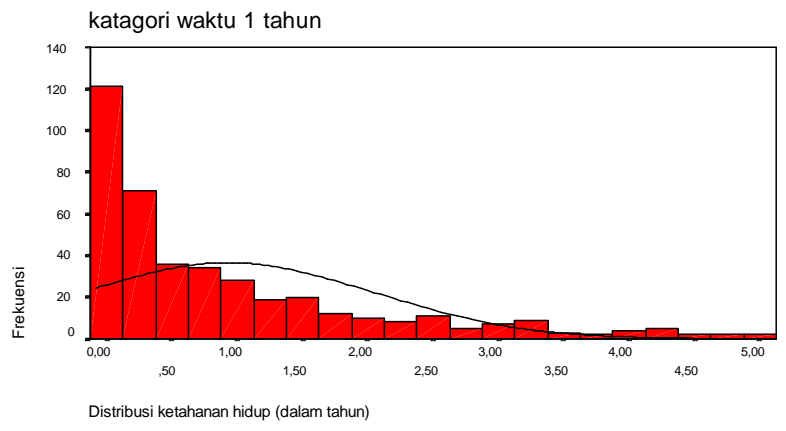




\section{Stadium Klinik}

Pasien yang datang berobat mulai dari stadium klinik 0 hingga IV B dan residif (kambuh). Pada stadium klinik I, frekuensi terbanyak ditemui pada stadium IB (19.9\%) dan paling sedikit adalah stadium IA $(0,2 \%)$. Pada stadium klinik II, frekuensi terbanyak ditemui pada stadium IIB $(20,5 \%)$ dan paling sedikit adalah stadium II $(0,7 \%)$. Pada stadium klinik III, frekuensi terbanyak ditemui pada stadium IIIB $(29,6 \%)$ dan paling sedikit adalah stadium IIIA $(0,7 \%)$. Sedangkan pada stadium klinik IV, frekuensi terbanyak ditemui pada stadium IVB $(3,2 \%)$ dan paling sedikit adalah stadium IV $(1,6 \%)$. Walaupun subyek residif tidak masuk ke dalam analisis tetapi didapatkan hasil yang menarik, yaitu dijumpai sebanyak 5\% dari total subyek. Secara umum dapat disimpulkan bahwa sebagian besar pasien datang ke rumah sakit dalam stadium lanjut (stadium IIB hingga IVB), yaitu 62,3\%.

Analisis selanjutnya, stadium klinik dikelompokkan menjadi 4 katagori, yaitu stadium I, II, III, dan IV. Frekuensi terbanyak ditemui pada stadium II (151 subyek), yaitu 36,7\%, stadium III (138 subyek) merupakan frekuensi terbanyak kedua, yaitu $33,6 \%$. Frekuensi stadium yang paling sedikit ditemui adalah stadium IV (34 subyek), yaitu 8,3\% dan stadium I ( 89 subyek) hanya 21,4\%. Sedangkan apabila stadium klinik dibagi menjadi stadium dini dan lanjut, diperoleh hasil 34,07\% stadium awal sedangkan $65,03 \%$ adalah stadium akhir.

\section{Hubungan Stadium klinik dengan ketahanan hidup 5 tahun}

Stadium klinik I (89 subyek) diperoleh median ketahanan hidup sebesar 5 tahun, probabilitas ketahanan hidup pada tahun pertama sebesar 76,5\% dan tahun kelima sebesar 70,2\%. Probabilitas ketahanan hidup 5 tahun pasien kanker serviks stadium II pada tahun pertama (143 subyek) sebesar $61,6 \%$ sedangkan probabilitas pada tahun kelima menjadi sebesar $37,5 \%$ dengan median ketahanan hidup sekitar 4,67 tahun. Pada stadium III (133 subyek) diperoleh median ketahanan hidup sebesar 0,94 tahun, probabilitas ketahanan hidup pada tahun pertama sebesar 23,6\% sedangkan probabilitas pada tahun kelima hanya sebesar 12,3\%. Sedangkan pada stadium IV (34 subyek) diketahui median ketahanan hidup hanya sekitar 0,68 tahun dengan probabilitas ketahanan hidup pada tahun pertama sebesar $8,9 \%$, dan pada tahun kedua probabilitas ketahanan hidup menjadi $0 \%$ (hal ini diartikan bahwa tidak satupun subyek yang masih hidup pada tahun kedua). Analisis statistik lanjut dengan uji Wilcoxon menunjukkan perbedaan yang signifikan $(\mathrm{p}=0,0000)$ antara stadium klinik I, II, III, dan IV dengan ketahanan hidup 5 tahun pada $\alpha=0,05$. Untuk lebih jelasnya lihat grafik 2

Grafik 2

Probabilitas Ketahanan Hidup Kanker Serviks menurut Stadium Kinik

RSUPN CM\&RSKD, 2002

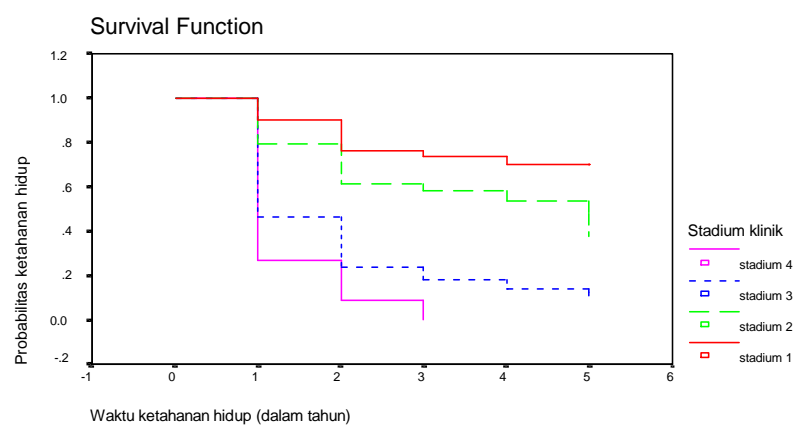

Hasil analisis dengan menggunakan regresi Cox diketahui bahwa dengan semakin meningkatnya stadium klinik pasien kanker serviks, maka risiko untuk meninggal semakin tinggi pula. Dibanding dengan stadium I, maka risiko meninggal untuk stadium II 2 kali lebih besar, stadium III 6,3 kali, dan stadium IV hampir 4 kalinya. Hasil uji menunjukkan bahwa ada perbedaan yang bermakna antara stadium dengan ketahanan hidup $(p=0,000)$

\section{PEMBAHASAN}

Penelitian ini menunjukkan bahwa dari semua pasien yang mengalami kematian sebanyak $43,5 \%$; tetap hidup $9,2 \%$; dan yang hilang dari pengamatan 47,3\%. Keadaan ini berbeda dengan laporan The International Federation of Gynecology and $\mathrm{Ob}$ stetrics (FIGO) pada tahun 1988 melaporkan bahwa yang mengalami kematian 34,7\%; hidup 53,5\%; 
serta yang hilang hanya 7,5\% (De Vita, dkk, 1997). Dari sini nampak bahwa pasien kanker serviks di Indonesia banyak yang tidak patuh kontrol/ periksa ulang setelah pulang dari RS. Kemungkinan lain yang terjadi adalah sistem pencatatan yang kurang pada RS atau dapat pula kartu berobat yang hilang sehingga pasien yang datang berobat ulang ketika kambuh memakai rekam medis yang baru.

Hasil penelitian menunjukkan sekitar 36, $7 \%$ (151 subyek) pasien datang berobat pada stadium II, kemudian pada stadium III dengan hasil tidak berbeda jauh, yaitu 33,6\% (138 subyek). Temuan ini sama dengan beberapa peneliti lain yang menyatakan bahwa umumnya pasien mencari pengobatan/datang ke fasilitas kesehatan sudah dalam stadium lanjut, yaitu sekitar $30-47 \%$ pasien datang pada stadium III, atau sekitar $70 \%$ pada stadium lanjut (Sirait,dkk, 1996; Sumardhi dan Sutoto, 1997; Gunadi, dkk, 1996; Litaay, dkk, 1999; Nandakumar, dkk, 1995).

Tingginya angka pasien yang datang pada stadium lanjut dan rendahnya pasien yang datang pada stadium dini dapat disebabkan beberapa hal, pertama karena penyakit kanker serviks jarang memberi gejala-gejala yang mengganggu pada stadium awal sehingga pasien tidak mengetahui dirinya telah terkena kanker serviks. Kedua, kurangnya promosi pelaksanaan pap smear yang sangat berguna untuk mendeteksi dini adanya kanker serviks. Gunadi, dkk, 1996 menemukan bahwa 100\% (126 subyek) yang datang ke RS menyatakan tidak pernah melakukan pemeriksaan pap smear.

Pada penelitian ini diketahui bahwa stadium klinik berbanding terbalik dengan lama ketahanan hidup, hal ini berarti semakin rendah stadium klinik pasien kanker serviks semakin tinggi pula ketahanan hidupnya. Diketahui bahwa probabilitas ketahanan hidup 5 tahun untuk stadium I sekitar $70,2 \%$, stadium II sekitar 37, 4\%, stadium III sekitar $12,4 \%$ sedang pada stadium IV pasien yang masih hidup hingga tahun kedua sehingga probabilitas hidup 5 tahun stadium ini adalah $0 \%$.

Hasil-hasil penelitian di luar negeri diketahui bahwa Angka Ketahanan Hidup (AKH) 5 tahun menurut Statistik Dunia pada diagnosa tahun 1959-1968 untuk stadium I sekitar 80, 5\%, stadium II sekitar 59, $1 \%$, stadium III sekitar 32, 8\%, sedangkan pada stadium IV hanya 7\% (Del Regato, dkk, 1985). Untuk diagnosa tahun 1979-1981, diketahui bahwa AKH 5 tahun pada stadium I sekitar 78, 1\%, stadium II sekitar $57 \%$, stadium III sekitar $31 \%$, dan stadium IV hanya 7, 8\%. Penelitian Horiot, dkk, 1988 (dalam De Vita, dkk, 1993) pada 1383 pasien yang dilakukan radioterapi di Perancis menyimpulkan AKH 5 tahun untuk stadium I sekitar $80 \%$, stadium II sekitar 66, 5\%, stadium III sekitar 48, 5\%, dan stadium IV sekitar 20, 5\%.

Apabila dibandingkan dengan hasil penelitian di luar negeri maka secara umum diketahui bahwa probabilitas ketahanan hidup pasien kanker serviks di Indonesia lebih rendah daripada di luar negeri. Adanya perbedaan ini dapat disebabkan, pertama oleh kurangnya fasilitas pelayanan kesehatan untuk meningkatkan kualitas hidup pasien kanker serviks. Kedua, kurangnya sosial-ekonomi pasien kanker serviks sehingga menyulitkan upaya penyembuhan secara tuntas. Ketiga, belum adanya registrasi kanker yang baik di Indonesia sehingga menyulitkan penelitian yang dapat menggambarkan secara tepat tentang keadaan di populasi tentang ketahanan hidup pasien kanker serviks. Keempat, letak fasilitas pelayanan ksehatan yang sulit dicapai sehingga menyulitkan pasien yang ingin mendapatkan pengobatan secara layak. Kelima, tidak adanya orang yang menemani pasien untuk melakukan pengobatan, hal ini dapat disebabkan pada umumnya pengantar dalam usia produktif yang harus bekerja untuk memenuhi kebutuhan sehingga pasien yang perlu ditemani tidak dapat melakukan pengobatan atau follow up.

\section{KESIMPULAN}

Probabilitas ketahanan hidup 5 tahun untuk stadium I sekitar 70,2\%, stadium II sekitar 37, $4 \%$, stadium III sekitar $12,4 \%$ sedang pada stadium IV pasien yang masih hidup hingga tahun kedua sehingga probabilitas hidup 5 tahun stadium ini adalah 0\%. Semakin meningkatnya stadium klinik pasien kanker serviks, maka risiko untuk meninggal semakin tinggi pula. Dibanding dengan 
stadium I, maka risiko meninggal untuk stadium II 2 kali lebih besar, stadium III 6,3 kali, dan stadium IV hampir 4 kalinya.

Hasil penelitian telah membuktikan bahwa semakin dini stadium kanker serviks maka peluang untuk tetap hidup dalam 5 tahun akan semakin meningkat, Oleh sebab itu untuk wanita yang telah menikah atau mempunyai risiko tinggi terkena kanker serviks secara teratur melakukan pemeriksaan pap-smear. Depkes sebaiknya melakukan promosi yang terus menerus tentang bahaya kanker serviks dan upaya pencegahannya meliputi faktor-faktor risiko terjadinya kanker serviks dan pentingnya melakukan pemeriksaan dini sebagai upaya pencegahan. (RS\&HH)

* Dewi Gayatri, SKp, MKes.: Staf pengajar bagian DKKD FIK-UI

** Besral, SKM, MSc; Staf pengajar jurusan biostatistik

*** Dra. Elly Nurachmah, D.N.Sc.: Dekan FIK UI, staf pengajar $S_{2} \& S_{1}$ FIK UI

\section{KEPUSTAKAAN}

Aziz, M.F.(1996).Kemoterapi pada kanker serviks. MOGI, 20 (3), 186-192.

Del Regato, J.A, Sprut, H.J, \& Cox, JD. (1985). Cancer, diagnosis, treatment, \& prognosis. Philadelphia: CV Mosby Company.

Depkes. (1996). Profil kesehatan Indonesia. Jakarta: Pusat data kesehatan.

De Vita, V.T, Hellman, S, \& Rosenberg, S.A, (1993). Cancer: Principles \& practice of oncology. (4 th ed). Philadelphia: JB Lippincott

De Vita, V.T, Hellman, S, \& Rosenberg, S.A. (1997).Cancer: Principles \& practice of oncology. (5 th ed). Philadelphia: Lippincott-raven publishers.

Gunadi. B, Rarung, \& Mewengkang. R.A.A, (1996). Tinjauan kasus penderita kanker leher rahim yang dirawat di RSUP Malalayang Manado peride 1 Januari 1993 - 31 Desember 1995. MOGI. Abstrak KOGI X. Suppl. 1, 26

Nandakumar. A, Anantha. N, \& Venugopal. TC, (1995). Incidence, mortality, \& survival in cancer of the cervix in Bangalor, India. British Journal of Cancer, 71 (6), 1348-1352.

Sirait. AM, Ariawan. I, \& Aziz. MF, (1997). Ketahanan hidup penderita kanker serviks di RS Dr Cipto Mangunkusumo Jakarta. MOGI. 21 (3), 182-190.

Sumardhi. W \& Sutoto, (1997). Hubungan trombositosis dengan kelangsungan hidup kanker serviks uteri. MOGI. 21 (3), 176-181. 